\title{
Ecological compensation for desertification control: A review
}

\author{
LI Dajing ${ }^{1,2}$, 'XU Duanyang ${ }^{1}$, WANG Ziyu ${ }^{3}$, DING Xue ${ }^{4}$, SONG Alin \\ 1. Institute of Geographic Sciences and Natural Resources Research, CAS, Beijing 100101, China; \\ 2. Central China Normal University, Wuhan 430079, China; \\ 3. Beijing Forestry University, Beijing 100083, China; \\ 4. Northeast Agricultural University, Harbin 150030, China; \\ 5. Institute of Agricultural Resources and Regional Planning, CAAS, Beijing 100081, China.
}

\begin{abstract}
Desertification control is a crucial way to enhancing the ecological conditions of arid and semi-arid regions, and maintaining sustainable development globally. Designing and improving an ecological compensation mechanism for desertification control has great significance related to achieving balance amongst the needs of different economic subjects and the assurance of a sustained and stable supply of desert ecosystem services. In this paper, (1) the theoretical bases of ecological compensation for desertification control were re-analyzed; (2) the research status and challenges of three important topics related to ecological compensation for desertification control were systemically discussed, including compensation standards, ecosystem service supply-consumption process and multi-scale effects, and resource-environment basis and policy orientation; (3) a research framework of ecological compensation for desertification control based on the process of desert ecosystem service supply-flow-consumption was proposed; (4) and finally, seven priority research issues were discussed, which aimed to support ecological compensation policy-making and ecological engineering implementation for desertification control.
\end{abstract}

Keywords: desertification control; ecosystem service; ecological compensation; evaluation system; scale

\section{Introduction}

Desertification is a land degradation process that is mainly caused by climate change and human activities in arid, semi-arid and some sub-humid regions (Wang, 2004; Adamo and Crews-Meyer, 2006; D’Odorico et al., 2013; Chasek et al., 2015; Salvati et al., 2015; Wijitkosum, 2016). Desertification has caused a loss of soil nutrients, a decline in land productivity and degradation of the environment. This leads to a decline or degradation of sand-stabilization, soil conservation, water resource regulation, carbon sequestration and other desert ecosystem services, and endangers both regional and national econ-

Received: 2017-03-30 Accepted: 2017-07-18

Foundation: National Natural Science Foundation of China, No.71573245; National Key Research and Development Program of China, No.2016YFC0501002

Author: Li Dajing (1993-), specialized in ecological compensation and regional development. E-mail: 695432485@qq.com

"Corresponding author: Xu Duanyang (1983-), PhD, specialized in desertification. E-mail: xudy@igsnrr.ac.cn 
omy-society-environmental security (Glenn et al., 1998; Unkovich and Nan, 2008; Xue et al., 2012; Martínez-Valderrama et al., 2016; Sutton et al., 2016). Research sponsored by the United Nations Environment Programme shows that the global economic losses caused by desertification and drought were as high as US $\$ 4.2 \times 10^{10}$ each year, which was equivalent to all official aid to Africa in 2009 (United Nations Convention to Combat Desertification (UNCCD), 2011).

Effective control of desertification requires long-term systematic efforts aimed at restoring the functions of desert ecosystem services and to realize the securing of both ecological and economic benefits. This will not only require the investment of large amounts of money and new technologies, but also get a relatively slow return. Particularly, the initial stage of desertification control will only require investments with very little or no initial return. In addition, other problems may arise during the final stage of desertification control such as the separation of investments and returns (Zhang, 2015). Therefore, it is essential to coordinate the interest-balancing among stakeholders in desertification control and improve the enthusiasm of those tasked with controlling desertification, to realize sustained control of desertification. United Nations Conference on Sustainable Development (Rio+20) in 2012 proposed establishing and achieving the goal of "Zero Net Land Degradation" by 2030, and regarded ecological compensation as an important measure that can be used to address land degradation (UNCCD, 2012). The "2030 Agenda for Sustainable Development," officially launched in January 1, 2016, established the goals of desertification control along with the suppression and reversal of land degradation, and proposed that participants should protect, restore and promote the sustainable use of land by using ecological compensation (OWG, 2014).

Ecological compensation can be treated as an integrated economic policy measure or a benefit compensation mechanism for realizing the interest-balancing of different economic subjects in environmental protection by constructing standard systems (Wunder, 2005; Lv et al., 2009; Home et al., 2014; Bennett and Gosnell, 2015; Wunder, 2015; Curran et al., 2016; Galati et al., 2016). As early as the 1870s, Larson and Mazzarse (1994) had proposed a rapid assessment model for wetlands for the issue of wetland development compensation permits, which initiated the preliminary study of ecological compensation. The Millennium Ecosystem Assessment (MA) has played a role as a milestone in the study of ecosystem services. It defined the framework of ecosystem services assessment, and resulted in an increase in

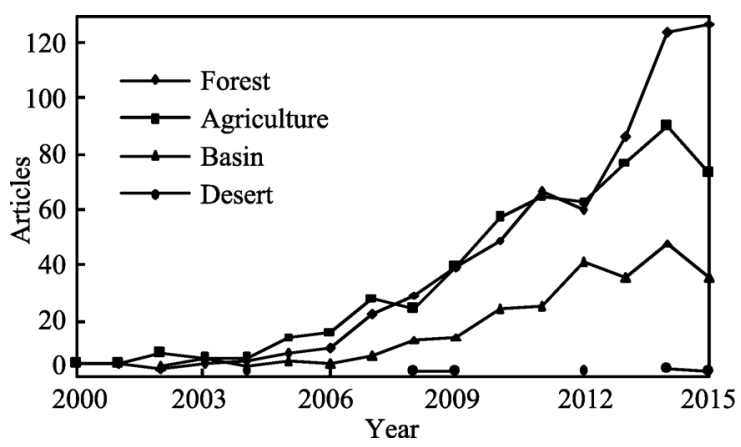

Figure 1 Research on ecological compensation in different areas of foreign countries in 2000-2015 theoretical and practical research worldwide on the problem of services and compensation for different ecosystems, including desert ecosystems (MA, 2003). However, many previous studies have mainly focused on ecological compensation for forests, agriculture, basins and other areas (Clements et al., 2010; Nguyen et al., 2013; Wünscher and Engel, 2012; Bennett et al., 2014; Kwayu et al., 2014; Hofstad et al., 2015), while relatively little research has been conducted 
on ecological compensation for desertification control (Figure 1).

China is one of the countries that have seriously suffered from desertification in the world, and the desertified lands are mainly distributed in Inner Mongolia, Ningxia, Gansu, Xinjiang, Qinghai, Shaanxi, Shanxi, Hebei and other provinces. According to the fifth national desertification survey statistics (SFA, 2015), the area of desertified land in China had reached $1,721,200 \mathrm{~km}^{2}$ in 2014 , which was reduced by $9900 \mathrm{~km}^{2}$ in 2009 ; and the desertification in some regions, like Erdos, North Shaanxi Province etc., had been reversed significantly. These desertification reversions can be attributed to the implementation of ecological protection projects and ecological compensation policies in recent years. For example, the cumulative input of ecological compensation from the Project of Returning Farmland to Forests and the Project of Sandstorm Sources of Beijing and Tianjin etc. reached about 800 billion yuan. Although the ecological compensation policy had been implemented about 10 years, less attention had been paid to systematically discussing the basic theory and key problems related to ecological compensation in support of desertification control. Therefore, based on reviewing the related literature, this paper aimed to re-analyze the theoretical basis and key problems related to ecological compensation, and propose a research framework and prioritize issues related to ecological compensation in support of desertification control.

\section{Theoretical basis of ecological compensation for desertification control}

The essence of desertification control is using engineering, biological, chemical and other measures to increase soil quality and vegetation coverage (Xu, 2003; Portnov and Safriel, 2004; Amiraslani and Dragovich, 2011). This can improve the level of ecosystem services provided by desert habitats and eventually realize an improvement in regional environmental quality. The result of desertification control has the characteristics of integrity, liquidity, positive externalities and regional differences. In addition, ecosystem service value theory, externality theory and public goods theory can be used as the theoretical basis for desertification control.

\subsection{Ecosystem service value theory}

Natural ecosystems provide raw materials and products (wood, fiber, etc.) that humans can use directly. Simultaneously, those ecosystems also provide the functions of supply, regulation, culture and support, which is beneficial to the survival and development of human beings (Sodhi et al., 2010; Allendorf and Yang, 2013; Sagie et al., 2013; Matthies et al., 2016; Mouchet et al., 2017). In 1997, Costanza et al. (1997) and Daily (1997) estimated the value of global ecosystem services as well as developed the principles and methods used in that valuation, but did not evaluate the value of desert ecosystem services. In 1999, Ouyang (1999) assessed the value of terrestrial ecosystem services in China, including desert ecosystems. Later, Xie et al. $(2003,2008)$ established and improved a service value table for desert ecosystems, which had important guiding significance for later studies. As an important type of terrestrial ecosystem, the value of desert ecosystem services is mainly reflected in the function of sand-stabilization, soil conservation, water resources regulation, biodiversity conservation and landscape-scale recreation, etc., which provides benefits and guarantees for residents living in sandy areas (Bai, 2003; Zhang and Yang, 2007; Gao et al., 2013; 
Wang, 2015). The results of desertification control are mainly embodied in the incremental value of these services. For example, a previous study in Yuyang District, Shaanxi Province, China showed that the Project of Returning Farmland to Forest and other ecological measures had led to an increase in the regional sand-stabilization function value of $5.64 \times 10^{6}$ yuan per year from 1988 to 2003 (Mo et al., 2006). Shapotou, a community situated in Zhongwei County, Ningxia Hui Autonomous Region, China, conducted large scale conversion of desertified land into timber and cultivated crop land from 2002 to 2011. The value of food supply, sand-stabilization, soil conservation, carbon sequestration, oxygen release and nutrient cycling functions increased by $7.04 \times 10^{6}, 3.00 \times 10^{7}, 1.37 \times 10^{7}, 9.36 \times 10^{6}, 7.51 \times$ $10^{6}$ and $2.42 \times 10^{6}$ yuan, respectively, in Shapotou over 10 years (Wang, 2015). Although putting a "price tag" on nature might raise inherently thought that the loss of ecosystem services can be replaced by man-made capital, quantitatively estimating and monetizing the value of desert ecosystem services is still critically needed; because this type of data can then be employed as an important reference for formulating the ecological compensation standards of desertification control.

\subsection{Externality theory}

Externality theory provides an important theoretical basis for determining losses and beneficiaries during ecological compensation. According to Marshall's "Principles of Economics" (Marshall, 1890), externality is the economic effects of different interests that occur when a producer's own interests generate external influences to others who are outside the economic exchange during the process of conducting economic activities. However, the influence of externality will not result in corresponding compensation from the marketplace or payment of the equal costs. Ecological compensation can serve as an important tool used to provide a favorable correction for this external influence. Generally, in the external economy, external beneficiaries are taxed or charged; while in the external diseconomy, the external losers are provided with subsidies to compensate them for their losses. The increased level of ecosystem services provided by controlling desertification always has a significant positive externality. This is especially true for sand-stabilization and soil conservation. Previous studies have shown that dust storms affecting eastern China were closely related to the control of desertification in western China (Gou et al., 2012; Chen, 2013). For example, with an increase in vegetation coverage in some sandy areas of northern China over the past 30 years, as measured by the Normalized Difference Vegetation Index (NDVI), the number and intensity of dust storm days in Beijing showed a decreasing trend from 2001 to 2010 (Figure 2). Meanwhile, some studies also found vegetation restoration in the Loess Plateau and in desert regions of western Inner Mongolia had effectively reduced soil erosion, which can enhance the soil conservation and the safety of residents in lower reaches of the Yellow River (Peng, 2013). Hartter and Goldman (2011) indicated that local precipitation and air quality of forest park in western Uganda had been improved as a result of efforts to protect forest ecosystems. It is easy to document the significantly positive externalities of sand-stabilization, soil conservation etc. in the process of controlling desertification, which will lead to inequalities of the investment and income of the entity controlling desertification. Therefore, levying a tax on beneficiaries to compensate the entity that controls desertification is indispensable, which will make ecological compensation an environmental economics instrument for the inter- 
nalization of external cost (Mao et al., 2002; Bartczak and Metelska-Szaniawska, 2015; Rodríguez-de-Francisco and Budds, 2015).

\subsection{Public goods theory}

Desert ecosystem services are nonexclusive and non-competitive, and can be classified in the category of public goods. In addition, controlling desertification also produces tradable goods, such as wood, herbs and industrial raw materials, etc., so

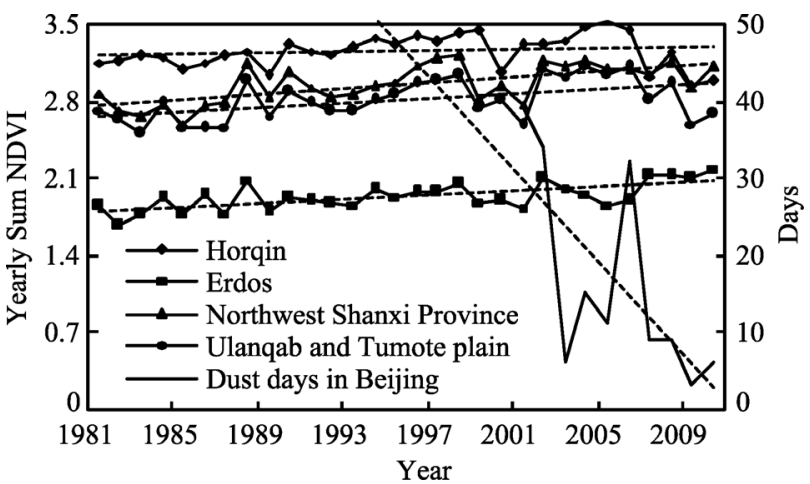

Figure 2 Changes of dust days in Beijing and NDVI in desert area treating it as a quasi-public good would be more accurate. This attribute of public goods in desertification ecosystem services might lead to excessive consumption of natural resources without supervision, and finally result in desertification, which is also called "Tragedy of the Commons". Take North China as an example, over the past few hundred years, especially in the past decades, the population growth and the excessively use of grassland and farm land had changed the traditional nomadic culture and resources using patterns (Zhang et al., 2017), which destroyed the ecological balance and led to rapid expansion of desertification (Figure 3). As another example of "Tragedy of the Commons" in Shiyang River of China, the over exploitation of groundwater had led to the death of oasis vegetation and a large-area of desertification in the periphery of the oasis (Ni et al., 2013).

From this perspective, the subject of desertification ecosystem services' supply should be the government. Due to the limited resources of government, it is often difficult to realize a sustained and effective supply of desert ecosystem services. Hence, many individuals or firms were expected to participate in desertification control. However, the result of these desertification control activities that conducted by individuals or firms cannot exclude others who enjoy the benefits, which might result in the creation of "free riders" and lead to a deficiency of ecosystem service supply (Hardin, 1968; Gatiso et al., 2015; Hu, 2015). The restoration of desertified land provides public goods that can be enjoyed by all the people in a

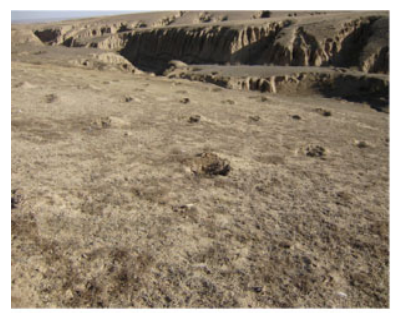

(a)

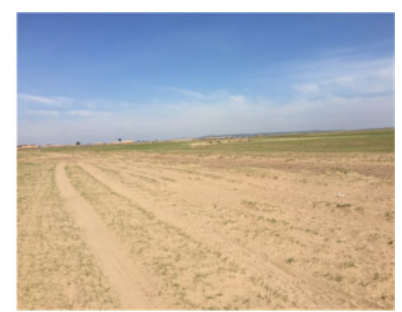

(b)

Figure 3 Photographs of desertification expansion: (a) Trees had died and removed in the next year after planting due to the absence of management. (b) Grassland desertification is serious due to the excavation of village road. (Photo credit: Duanyang $\mathrm{Xu}$ obtained the pictures in October 2011 (a) and August 2016 (b))

sandy area and the adjoining region, so the government needs to use service-purchasing or other market mechanisms to maximize the generation and expansion of these services. However, when the entity tasked with controlling desertification was an individual or firm, that entity must solve the problem of recovering the costs of controlling desertification. Therefore, it is necessary to reduce the high cost of 
controlling desertification during the initial stage by using ecological compensation, which would create effective incentives for desertification control and eventually realize a sustained supply of desert ecosystem services.

\section{Important problems related to ecological compensation for controlling desertification}

\subsection{Standard accounting for ecological compensation during desertification control}

The compensation standard is a critical part of the implementation of ecological compensation for controlling desertification. However, it varied greatly in different regions, which ranging from 1000 to $10,000 \mathrm{yuan} / \mathrm{ha} \cdot \mathrm{a}$. Take Britain as an example, the government paid about $1091 \mathrm{yuan} / \mathrm{ha} \cdot \mathrm{a}$ to farmers who returned farmland to forests for compensation in 30 years (Green, 1989). For the Project of Returning Farmland to Forests launched in China, the compensation standard in the Yellow River basin and its northern region is about 1050 yuan/ha·a (Ning, 2010); and for the Project of Sandstorm Sources of Beijing and Tianjin, the government had provided subsidies about 8250 yuan/ha·a to farmers in the sandy regions (Pan, 2014). The differences of compensation standard are mainly dependent on the value of desert ecosystem services. Generally, three factors affect the ecological compensation standards: the scope of desert ecosystem services, modeling and the method used for valuation. However, different scholars have created different definitions of these three factors, which means their assessment results cannot be easily compared. Meanwhile, some studies have also been carried out to assess the loss value of economic and social system that caused by land degradation or desertification. As illustrated in Table 1, although both Wang (2015) and Yang and Wang (2009) assessed the ecosystem services in Shapotou in China, they placed different values on ecosystem services in their research. Those differences were mainly caused by differences in their assessment of service functions of the desert landscape. In addition, many uncertainties remain related to parameter acquisition and evaluation methods. For instance, Yang et al. (2006) calculated the sand-stabilization value of the Hotan River Basin in China based on forest area, while Han et al. (2011) calculated the same service value in the downstream region of the Heihe River in China by using the amount of sand-stabilization provided by vegetation.

In 2012, the State Forestry Administration of China promulgated the forestry industry standard "Desert Ecosystem Service Evaluation Norms" (LY/T 2006-2012), which is a useful exploration in constructing an assessment framework of desert ecosystem services. However, it does not consider the spatial heterogeneity of land surface environment and its impact on modeling parameters. To avoid these limitations, some scholars began to combine multi-source and high-resolution remote sensing data to retrieve the parameters at a regional scale (Luo et al., 2014). So, the difference and optimization method of the key parameters should be fully considered at a national scale, such as crop yield, soil organic matter and surface roughness etc.; meanwhile, specific adjustment and correction for parameters and methods are also needed (Chun, 2011). It should also be pointed out that some desert ecosystem services are invisible, such as water purification, biodiversity conservation and landscape recreation, and subjectivity during an evaluation would lead to uncertainties in the accounting compensation standard (Cui, 2009; Gee and Burkhard, 2010; Bidak et al., 2015). In addition, the formation mechanism of desert ecosystem services must be clarified. There- 
fore, knowing how to quantitatively identify the individual contribution of human activities and climate change, and how to analyze the marginal effects of different policies, still creates a difficult problem in accounting for ecological compensation standards.

Table 1 Standard of desert ecosystem service value by different scholars

\begin{tabular}{|c|c|c|c|c|c|}
\hline Nation & Study area & Assessment content & $\begin{array}{c}\text { Total value } \\
\text { (yuan/a) }\end{array}$ & $\begin{array}{c}\text { Unit area value } \\
\text { (yuan } / \mathrm{a} \cdot \mathrm{km}^{2} \text { ) }\end{array}$ & Literature source \\
\hline USA & $\begin{array}{l}\text { California } \\
\text { desert }\end{array}$ & $\begin{array}{l}\text { Direct, indirect and pas- } \\
\text { sive use values }\end{array}$ & $\begin{array}{c}1.33 \times 10^{9} \\
\text { dollars }\end{array}$ & & Richardson (2005) \\
\hline USA & Mojave desert & $\begin{array}{l}\text { Direct, indirect and pas- } \\
\text { sive use values }\end{array}$ & $\begin{array}{c}1.42 \times 10^{9} \\
\text { dollars }\end{array}$ & & $\begin{array}{l}\text { Kroeger and } \\
\text { Manalo (2007) }\end{array}$ \\
\hline World & World & $\begin{array}{l}\text { Loss value of land degra- } \\
\text { dation }\end{array}$ & $6.25 \times 10^{13}$ & $4.64 \times 10^{5}$ & Sutton et al. (2016) \\
\hline Mexico & $\begin{array}{l}\text { Coastal } \\
\text { Wetlands }\end{array}$ & $\begin{array}{l}\text { Loss value of land use } \\
\text { change }\end{array}$ & $18.44 \times 10^{6}$ & $7.34 \times 10^{3}$ & $\begin{array}{l}\text { Camacho-Valdez } \\
\text { et al. }(2014)\end{array}$ \\
\hline USA & New Jersey & Loss value of sandy storm & $4.4 \times 10^{9}$ & $5.57 \times 10^{4}$ & Hauser et al. (2015) \\
\hline China & China & Hydrological regulation & $5.51 \times 10^{12}$ & $4.15 \times 10^{5}$ & Xiao et al. (2013) \\
\hline China & China & $\begin{array}{l}\text { Carbon fixation and oxy- } \\
\text { gen release; Nutrient cy- } \\
\text { cling; Sand-stabilization; } \\
\text { Water and soil conserva- } \\
\text { tion; Biodiversity conser- } \\
\text { vation; Tour etc. }\end{array}$ & $2.28 \times 10^{11}$ & $1.87 \times 10^{5}$ & Cui (2009) \\
\hline China & China & $\begin{array}{l}\text { Sand-stabilization; Soil } \\
\text { conservation; Water re- } \\
\text { sources regulation; Carbon } \\
\text { fixation; Biodiversity } \\
\text { conservation; landscape } \\
\text { recreation etc. }\end{array}$ & $3.08 \times 10^{13}$ & $1.87 \times 10^{7}$ & $\begin{array}{l}\text { Project group } \\
(2014)\end{array}$ \\
\hline China & $\begin{array}{l}\text { Western } \\
\text { region }\end{array}$ & $\begin{array}{l}\text { Carbon fixation and oxy- } \\
\text { gen release; Soil conserva- } \\
\text { tion etc. }\end{array}$ & $5.37 \times 10^{11}$ & $0.78 \times 10^{5}$ & Ren et al. (2007) \\
\hline China & $\begin{array}{l}\text { Ejin Horo } \\
\text { Banner in } \\
\text { Inner Mongolia }\end{array}$ & $\begin{array}{l}\text { Soil conservation; Climate } \\
\text { regulation etc. }\end{array}$ & $3.3 \times 10^{9}$ & $5.49 \times 10^{5}$ & Bai (2003) \\
\hline China & $\begin{array}{l}\text { Shapotou in } \\
\text { Ningxia }\end{array}$ & $\begin{array}{l}\text { Carbon fixation and oxy- } \\
\text { gen release; Nutrient cy- } \\
\text { cling; Food supply; } \\
\text { Sand-stabilization; Water } \\
\text { and soil conservation etc. }\end{array}$ & $1.55 \times 10^{8}$ & $1.11 \times 10^{6}$ & Wang (2015) \\
\hline China & $\begin{array}{l}\text { Ulan Buh in } \\
\text { Inner Mongolia }\end{array}$ & Sand-stabilization & $4.42 \times 10^{9}$ & $4.87 \times 10^{5}$ & Gao et al. (2013) \\
\hline China & $\begin{array}{l}\text { Neiman Banner } \\
\text { in Inner Mon- } \\
\text { golia }\end{array}$ & $\begin{array}{l}\text { Gas regulation; Climate } \\
\text { regulation; Water conser- } \\
\text { vation; Soil formation and } \\
\text { protection; Waste disposal; } \\
\text { Biodiversity conservation; } \\
\text { Food production; Raw } \\
\text { material; Entertainment } \\
\text { culture etc. }\end{array}$ & $1.49 \times 10^{9}$ & $1.84 \times 10^{6}$ & Chun (2011) \\
\hline China & $\begin{array}{l}\text { Qiemo Oasis in } \\
\text { Xinjiang }\end{array}$ & Ditto & $2.69 \times 10^{8}$ & $3.71 \times 10^{5}$ & Huang et al. (2007) \\
\hline China & $\begin{array}{l}\text { Qitai Oasis in } \\
\text { Xinjiang }\end{array}$ & Ditto & $5.29 \times 10^{8}$ & $1.23 \times 10^{5}$ & Peng et al.(2010) \\
\hline
\end{tabular}


(Continued)

\begin{tabular}{|c|c|c|c|c|c|}
\hline Nation & Study area & Assessment content & $\begin{array}{c}\text { Total value } \\
\text { (yuan/a) }\end{array}$ & $\begin{array}{c}\text { Unit area value } \\
\left(\text { yuan } / \mathrm{a} \cdot \mathrm{km}^{2}\right)\end{array}$ & Literature source \\
\hline China & $\begin{array}{l}\text { Kuqa River in } \\
\text { Xinjiang }\end{array}$ & Ditto & $1.90 \times 10^{10}$ & $3.39 \times 10^{6}$ & Zhang et al.(2009) \\
\hline China & $\begin{array}{l}\text { Minqin Oasis } \\
\text { in Gansu }\end{array}$ & Ditto & $5.58 \times 10^{8}$ & $3.72 \times 10^{4}$ & $\begin{array}{l}\text { Yang and Bai } \\
(2009)\end{array}$ \\
\hline China & $\begin{array}{l}\text { Shapotou in } \\
\text { Ningxia }\end{array}$ & Sand-stabilization & $5.93 \times 10^{8}$ & $5.29 \times 10^{7}$ & $\begin{array}{l}\text { Yang and Wang } \\
\text { (2009) }\end{array}$ \\
\hline China & $\begin{array}{l}\text { Hotan River } \\
\text { Basin in Xinj- } \\
\text { iang }\end{array}$ & $\begin{array}{l}\text { Organic matter production; } \\
\text { Climate regulation; Soil } \\
\text { formation and protection; } \\
\text { Water regulation; Clean- } \\
\text { sing of environmental pol- } \\
\text { lution; Biodiversity conser- } \\
\text { vation; Entertainment cul- } \\
\text { ture; Wood products; Indu- } \\
\text { stry material etc. }\end{array}$ & $6.72 \times 10^{8}$ & $2.11 \times 10^{6}$ & Yang et al. (2006) \\
\hline China & $\begin{array}{l}\text { Horqin in Inn- } \\
\text { er Mongolia }\end{array}$ & $\begin{array}{l}\text { Waste disposal; Soil for- } \\
\text { mation and protection; } \\
\text { Water conservation; Cli- } \\
\text { mate regulation; Biodiver- } \\
\text { sity conservation; Gas } \\
\text { regulation etc. }\end{array}$ & $1.46 \times 10^{11}$ & $2.82 \times 10^{6}$ & Zhang et al. (2007) \\
\hline China & $\begin{array}{l}\text { Heihe River in } \\
\text { Inner Mongo- } \\
\text { lia }\end{array}$ & Sand-stabilization & $5.31 \times 10^{9}$ & $4.78 \times 10^{5}$ & Han et al. (2011) \\
\hline
\end{tabular}

\subsection{Spatial-temporal patterns of desert ecosystem service supply-consumption and its multi-scale effect}

Identifying the desert ecosystem service supply-consumption subjects at multiple scales is an important prerequisite during the implementation of ecological compensation (De Groot et al., 2002; Kolinjivadi et al., 2014; Liu et al., 2014); in addition, the MA had also emphasized the importance of multi-level ecosystem service assessment (MA, 2005). For example, the food supply function is mainly applicable to the local scale; sand-stabilization, soil conservation and water resource regulation functions are mainly applicable to a regional scale; and climate regulation function is more reflected in national and intercontinental scales (Zhao and Zhang, 2006). Because of the spatial heterogeneity and multi-scale effect on the supply-consumption subjects of desert ecosystem services (Figure 4), it is crucial to analyze the spatial path of the ecosystem service flow and its influence on the ecological compensation policies at different scales.

With the spatial mobility of the results of controlling desertification, the geographical locations of the providers and beneficiaries of desertification control are not necessarily the same. This also brings some difficulties in determining who are the stakeholders in ecological compensation efforts. Generally, at a continental scale, compensation always occurs in different nations, such as developed countries may compensate developing countries because desertification can be induced by global climate change. For instance, Zambia and Zimbabwe, two signatories of the UNCCD, both suffer from the adverse effects of climate change, resulting in poor and even economic contraction in the agricultural sector (Twomlow et al., 2008). At a national scale, compensation should be focused on different regions 


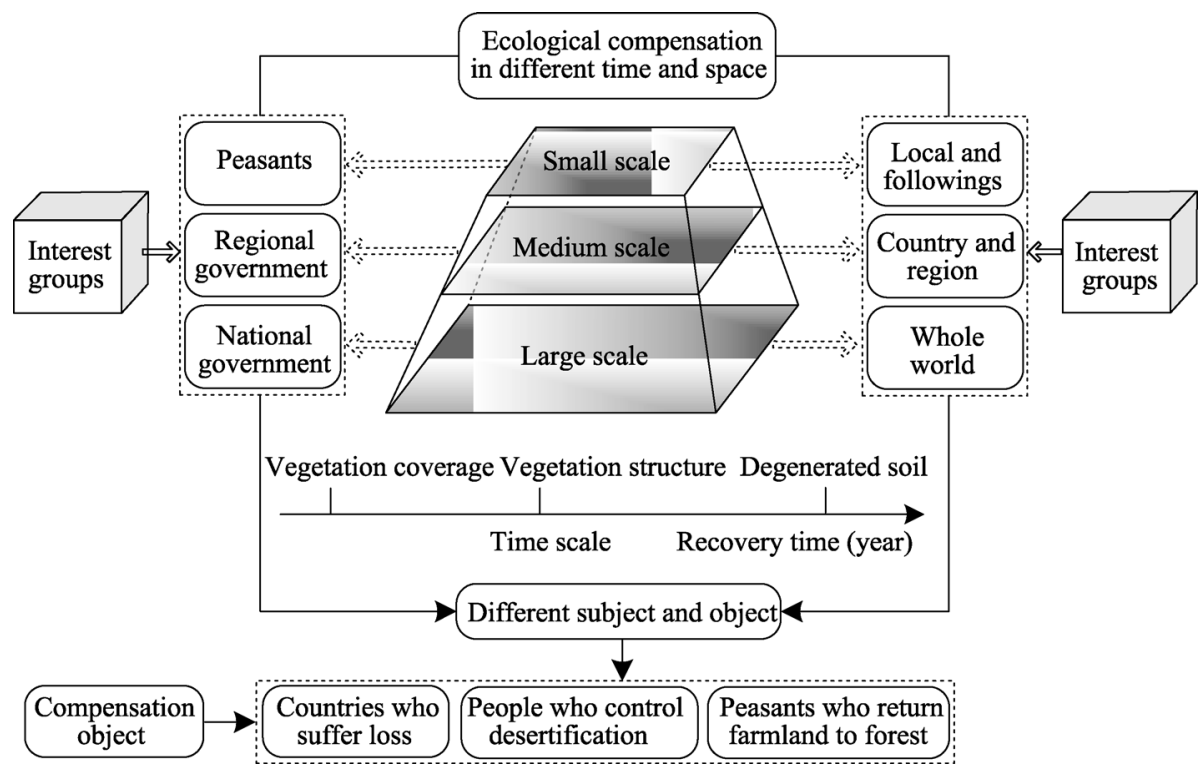

Figure 4 The difference of the supply-consumption subjects of desert ecosystem services at different scales

within the interior of a nation, and the majority of stakeholders are the agents of the supply of ecosystem services, such as regional governments. At a local scale, attention should focus on the interaction of ecological compensation and farmers' livelihoods, including the degree of participation by farmers, the enthusiasm of farmers in participating in a project and the entire lifecycle accounting of the opportunity costs in desertification control. Studies of the Sahel region of Africa suggest that poverty alleviation through the carbon sink projects effectively increase the income of local residents, and market-oriented measures can strengthen the potential for sustainable development in small scale agricultural systems (Tschakert, 2007). On a time scale, the control of desertification is a long-term project, and it generates revenue relatively slowly. More concretely, during efforts to control desertification the restoration of vegetation coverage and structure will take more than 10 years, and the restoration of degraded soil will require at least a few decades or may even require more than 100 years (Wuriga, 2013). Hence, the beneficiaries of desertification control include people who have yet to be born, and the determination of stakeholders often includes the problem of intergenerational compensation. Because different descendants of the present generation will enjoy different ecosystem services, the determination of compensation standards needs to take full account of the allocation and reduction of the control costs at different time scales (Kosoy et al., 2008).

\subsection{Resource-environmental basis and policy of sustained desert ecosystem services supply}

Because of the public ownership of desertification control, problems such as those related to the "Tragedy of the Commons" and "free-riders" always exist and will lead to an insufficient supply of ecosystem services. The purpose of ecological compensation is to ensure a sustained supply of desert ecosystem services, with the goal of ultimately achieving continuous improvement of the regional environment. In recent decades, many policies or projects have been launched to control desertification all over the world. The most representative one is 
the Conservation Reserve Program (CRP) in United States, which offered 10-15 year contracts for retirement of land from crop production, and provided cost-sharing for establishment of cover (usually grass or trees) and an annual payment (Claassen et al., 2008). Furthermore, the Forests Absorbing Carbon-dioxide Emissions Forestation Program (PROFAFOR) in Ecuador (Wunder and Albán, 2008), the Payment for Hydrological Environmental Services (PSAH) in Mexico (Muñoz-Piña et al., 2008), and the Project of Returning Farmland to Forest in China (Li and Shi, 2015) are also the favorable paradigms for ecological compensation policy. However, in view of the spatial heterogeneity of desertification control, to realize a sustainable supply of ecosystem services and reduce the dependence on a direct compensation fund, a balance also needs to be achieved among desertification control, environmental resources and economic development at national and regional scales.

Specifically, at a national scale, by considering the regional differences in resource availability and bearing capacity, desertification control in different forms and intensity are carried out, which would realize an indirect reduction of ecological compensation expenses. However, regional differences in resource-environmental capacity have not been fully considered in previous desertification control efforts. We take the afforestation activities in northern China as an example. Although statistical data had matched the regional natural conditions quite well, some areas still suffered from excessive or insufficient afforestation, which was likely to result in regional ecological risk or a waste of resources (Figure 5). Some studies show that afforestation will have significant effects on the regional water balance and ecological security. For example, Feng et al. (2016) found that although afforestation resulted in an increase in net primary production (NPP) and evapotranspiration (ET), it also resulted in the decrease in annual precipitation in a catchment area. Cao et al. (2007) found that large-scale afforestation in the Loess Plateau of China is likely to lead to excessive consumption of soil moisture, and ultimately increase the risk of desertification and economic losses. The studies of Lu et al. (2016) and Zhang et al. (2016) reached similar conclusions. Therefore, it is crucial to scientifically plan and develop ecological restoration projects based on regional resource endowment, which can ensure a sustained supply of ecosystem services and reduce the cost of ecological compensation for desertification control.

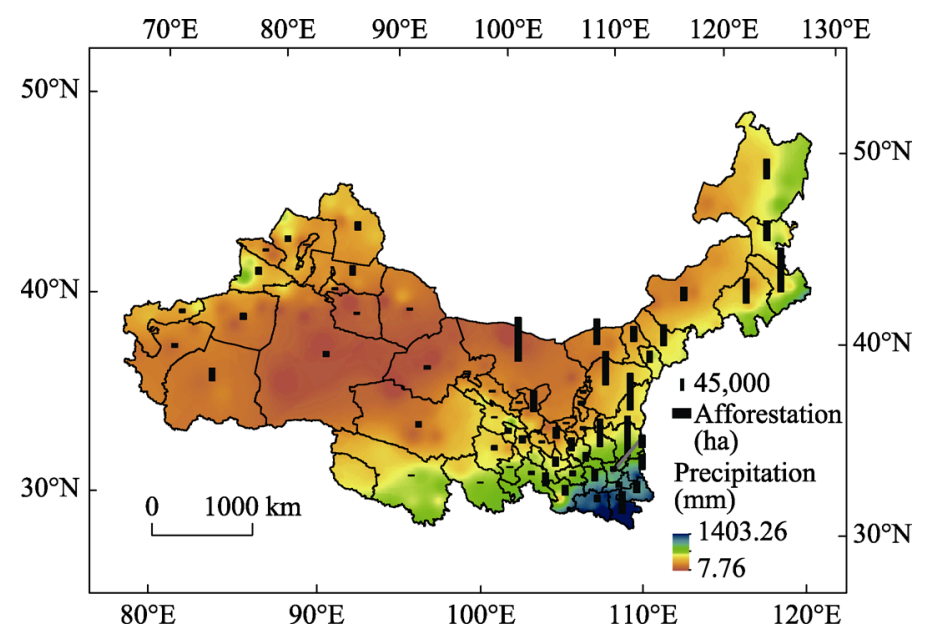

Figure 5 Distribution of precipitation and afforestation in arid and semi-arid areas of northern China 
At a regional scale, more attention should be focused on the balance between desertification control and economic development. Based on the basic framework of ecological compensation, direct financial compensation provided by regions benefiting from ecosystem services is an important guarantee for supporting the control of desertification. However, fundamentally solving the problems related to long-term sustained control of desertification is difficult when using this compensation method. To realize a "win-win" situation related to both desertification control and sustainable economic development, it is necessary to stimulate the enthusiasm of local farmers and enterprises and gain their participation and cooperation in these efforts. In recent years, Inner Mongolia, Qinghai and Ningxia in China have begun to develop the concept of desert-based industry to combat desertification (Zhang et al., 2007; Xie et al., 2013; Liu et al., 2015). For instance, in Alashan, Inner Mongolia, China, by developing the farming of Haloxylon-Cistanche, two genera of useful plants, the yield of Cistanche increased from 200 to 800-1000 tons per year in Inner Mongolia, which not only increased the income of farmers, but also achieved the goal of combating desertification (Tian and Gao, 2013). Therefore, government agencies need to explore methods of diversifying ecological compensation, with a certain amount of funds and related policies used to compensate for the major costs to farmers along with corporate governance of projects during the initial stage of investment. Ultimately, government agencies need to promote the formation of a desertification control industry and stimulate healthy economic development in the same region simultaneously.

\section{Research framework and priority issues related to ecological compensa- tion for desertification control}

\subsection{Research framework of ecological compensation for desertification control}

Although a considerable amount of progress has been made in the field of ecological compensation for desertification control, it is still necessary to develop a research framework that covers priority issues from basic research to comprehensive decision making (Figure 6). Based on related theory and the key problems, ecological compensation for desertification control should be examined from the perspective of regionality, comprehensiveness and scale correlation. The improvement of the desert ecosystem services classification system should be based on the supply-flow-consumption of desert ecosystem services. The goal is to improve the key service functions related to the formation of those services, the process of service flow, and to understand the relationship between the internal and external economic and social impact of desert ecosystem services at different spatial and temporal scales. It is crucial to clarify the resource environment basis and policy orientation of sustained supply of desert ecosystem services, which can provide comprehensive support for innovation based on theories and help policy makers develop practical methods of ecological compensation related to desertification control.

\subsection{Priority issues related to ecological compensation for desertification control}

(1) A desert ecosystem service classification system with integrated function-demand and its definition. Currently, most definitions of desert ecosystem service functions are based on the MA classification system that highlights the components, structures and processes of 




Figure 6 Research framework of ecological compensation for desertification control

desert ecosystem services from the supply perspective. However, less consideration has been given to the actual needs of human society and well-being (Zhang et al., 2010). Therefore, the spatial heterogeneity of the ecosystem service supply and consumption requires more attention. It is crucial to systematically review the relationship between desertification ecosystem functions and human needs during different stages of economic development. $\mathrm{Hu}-$ man health, ecological security, water supply, etc., should be considered and a new desert ecosystem services classification system should be established.

(2) Formation mechanism of desert ecosystem services and its response to global change. On-site field observations, controlled experiments in both indoor and outdoor settings, model simulation and other related measures should be fully used to study the mechanisms involved during the formation of the most important desert ecosystem services, including sand-stabilization, soil conservation, carbon sequestration and water resource regulation, etc. It is essential to explore dynamic models of the formation and evolution of desert ecosystem services, and analyze the response of desert ecosystems to climate change and human activities at different scales. Quantitatively separating and identifying the marginal benefits of individual human factors in the formation of desert ecosystem services are also needed, which can provide the basis for the scientific establishment of compensation standards.

(3) Spatial-temporal pattern and evolutional simulation of desert ecosystem service flow on different scales. Cross-coupling application of test methods (including isotopic geochemical tracer techniques and fluorescent labeling), spatial analysis of geo-information and remote sensing observation should be focused to scientifically define the source, spatial flow path, attenuation rate and occurrence law, etc. of desert ecosystem services. Meanwhile, it is 
necessary to improve our ability to spatially and temporally simulate the flow of desert ecosystem services under different environmental conditions and policy scenarios, and accurately identify the regions benefiting from desert ecosystem services to help policy makers to develop reasonable ecological compensation plans.

(4) Compensation standard and dose-effect relationship between desert ecosystem services and economic-social impact. Because a result of avoiding loss is equivalent to the benefits obtained, it is needed to quantitatively evaluate the contribution of desertification control to the entire human economic-social system from the perspective of service-revenue-welfare (Li et al., 2013), propose the suitable scope of compensation standard in different areas and analyze its impact on the livelihoods of farmers, government expenditure and the formation of ecosystem services. To this end, researchers should thoroughly study the effect mechanisms, and constantly improve the quantitative methods used to manage revenues. Policy making should actively introduce a substitute market method and simulation market method, such as using the willingness-to-pay and hedonic price methods (Dai et al., 2012; Zhao and Zhu, 2015). Meanwhile, scientific accounting of desertification control costs should be strengthened to provide a sound basis for ecological compensation standards.

(5) Resource and environment carrying capacity and space optimization layout of desertification control. According to the typical water demand characteristics of vegetation and the influence of afforestation on soil moisture, the limited role of water resources in desertification control and the formation of ecosystem services should be fully considered. The goal here is to improve research related to resources and environmental carrying capacity related to desertification control in arid and semi-arid regions. Based on available resources and environmental carrying capacity, the level of economic development, the comprehensive control of cost and other factors, planners need to optimize the spatial layout of desertification control, and from the perspective of regional balance to indirectly improve control efficiency and reduce the cost of ecological compensation.

(6) Policy basis and compensation mechanism innovation of desert-based industry. Relying on the advantages of regional resources, the comprehensive technological-economic-ecological benefits evaluation model should be developed to select the advantaged desert-based industry. What's more, it is essential to conduct a study of the policy system related to innovation-driven development in desert-based industry, and explore the diversified compensation methods of technical assistance, talent introduction, cooperative $R \& D$, carbon trading, etc., which can weaken our dependence on direct subsidies and create new channels for the development of the desertification control industry and ecological compensation.

(7) Data system construction and sharing for supporting ecological compensation related to desertification control. The development of integrated satellite and on-the-ground observation network should be paid more attention to retrieve key elements of the land surface in arid and semi-arid areas. Meanwhile, additional efforts should be implemented to optimize joint inversion and assimilation algorithms using multi-source remote sensing data, and scale correction factors of parametric estimation to overcome the estimation error of single scale and single data sources. In addition, the inversion precision of surface roughness, vegetation coverage, soil moisture and other important parameters need to be improved. Finally, developing and sharing high-resolution data products should be strengthened on a 
global scale to support scientific research and practice of ecological compensation for desertification control.

\section{Conclusions}

(1) A scientific evaluation of the value of desert ecosystem services provides the basis for the establishment of an ecological compensation standard. Currently, the estimation of the volume of the desert ecosystem services is relatively accurate, while knowing the value of those services is still the weak link in future evaluation work.

(2) Based on the full consideration of ecosystem services value theory, externality theory and public goods theory, the spatial-temporal scale is introduced into the definition of an ecological compensation standard. This allows the definition of the flow path of desertification control results as well as resources and environment foundation, and provides a basis for the scientific control of desertification control activities and policy-making related to ecological compensation.

(3) It can easily be noticed that ecological compensation for desertification control should take full consideration of the characteristic difference and dominant factors in different regions, tightly around the main line of desert ecosystem service supply-flow-consumption. A research framework should be formed for ecological compensation for desertification control from basic research to comprehensive decision making, and finally inform the public about the positive effects of a desert ecosystem.

(4) With the inter-science crossing and integrated innovation of economics, ecology, geography and other disciplines, and a wide application of a variety of mathematical models in the desert ecosystem services assessment, there are more possibilities to scientifically construct ecological compensation standards.

\section{References}

Adamo S B, Crews-Meyer K A, 2006. Aridity and desertification: Exploring environmental hazards in Jáchal, Argentina. Applied Geography, 26: 61-85.

Allendorf T D, Yang J, 2013. The role of ecosystem services in park-people relationships: The case of Gaoligongshan Nature Reserve in Southwest China. Biological Conservation, 167: 187-193.

Amiraslani F, Dragovich D, 2011. Combating desertification in Iran over the last 50 years: An overview of changing approaches. Journal of Environmental Management, 92: 1-13.

Bai X F, 2003. The evaluation of ecosystem services value of land use in desertification area: A case study in Yijihuoluo [D]. Beijing: China Agricultural University. (in Chinese)

Bartczak A, Metelska-Szaniawska K, 2015. Should we pay, and to whom, for biodiversity enhancement in private forests? An empirical study of attitudes towards payments for forest ecosystem services in Poland. Land Use Policy, 48: 261-269.

Bennett D E, Gosnell H, Lurie S et al., 2014. Utility engagement with payments for watershed services in the United States. Ecosystem Services, 8: 56-64.

Bennett D E, Gosnell H, 2015. Integrating multiple perspectives on payments for ecosystem services through a social-ecological systems framework. Ecological Economics, 116: 172-181.

Bidak L M, Kamal S A, Halmy M W A et al., 2015. Goods and services provided by native plants in desert ecosystems: Examples from the northwestern coastal desert of Egypt. Global Ecology and Conservation, 3: 433-447.

Camacho-Valdez V, Ruiz-Luna A, Ghermandi A et al., 2014. Effects of land use changes on the ecosystem service values of coastal wetlands. Environmental Management, 54(4): 852-864. 
Cao S X, Chen L, Xu C G et al., 2007. Impact of three soil types on afforestation in China's Loess Plateau: Growth and survival of six tree species and their effects on soil properties. Landscape and Urban Planning, 83(2/3): 208-217.

Chasek P, Safriel U, Shikongo S et al., 2015. Operationalizing zero net land degradation: The next stage in international efforts to combat desertification? Journal of Arid Environments, 112: 5-13.

Chen Y H, 2013. Study on relationship between the climatic factors in Northwest China and the sandstorm [D]. Nanjing: Nanjing University of Information Engineering. (in Chinese)

Chun M, 2011. Research on ecological compensation mechanism of cultivated land in desertification area: A case study of Naiman Banner [D]. Hohhot: Inner Mongolia Normal University. (in Chinese)

Claassen R, Cattaneo A, Johansson R, 2008. Cost-effective design of agri-environmental payment programs: US experience in theory and practice. Ecological Economics, 65: 737-752.

Clements T, John A, Nielsen K et al., 2010. Payments for biodiversity conservation in the context of weak institutions: Comparison of three programs from Cambodia. Ecological Economics, 69: 1283-1291.

Costanza R, D Arge R, De Groot R et al., 1997. The value of the world's ecosystem services and natural capital. Nature, 387(6630): 253-260.

Cui X H, 2009. Valuation of terrestrial ecosystem services and values: A case study of desert ecosystems in China [D]. Beijing: Chinese Academy of Forestry. (in Chinese)

Curran M, Kiteme B, Wünscher T et al., 2016. Pay the farmer, or buy the land? Cost-effectiveness of payments for ecosystem services versus land purchases or easements in Central Kenya. Ecological Economics, 127: 59-67.

Dai J H, Wang H J, Wang H L et al., 2012. An introduction to framework of assessment of the value of ecosystem services. Progress in Geography, 31(7): 963-969. (in Chinese)

Daily G C, 1997. Nature's services: Societal dependence on natural ecosystems. Washington DC: Island Press.

De Groot R S, Wilson M A, Boumans R M J, 2002. A typology for the classification, description and valuation of ecosystem functions, goods and services. Ecological Economics, 41(3): 393-408.

D'Odorico P, Bhattachan A, Davis K F et al., 2013. Global desertification: Drivers and feedbacks. Advances in Water Resources, 51: 326-344.

Feng X M, Fu B J, Piao S L et al., 2016. Revegetation in China's Loess Plateau is approaching sustainable water resource limits. Nature Climate Change, 6: 1019-1022.

Galati A, Crescimanno M, Gristina L et al., 2016. Actual provision as an alternative criterion to improve the efficiency of payments for ecosystem services for C sequestration in semiarid vineyards. Agricultural Systems, 114: 58-64.

Gao J L, Hao Y G, Ding G D et al., 2013. Primary assessment on the wind-breaking and sand-fixing function of the vegetation and its value in Ulan Buh desert ecosystem. Journal of Arid Land Resources and Environment, 27(12): 41-46. (in Chinese)

Gatiso T T, Vollan B, Nuppenau E A, 2015. Resource scarcity and democratic elections in commons dilemmas: An experiment on forest use in Ethiopia. Ecological Economics, 114: 199-207.

Gee K, Burkhard B, 2010. Cultural ecosystem services in the context of offshore wind farming: A case study from the west coast of Schleswig-Holstein. Ecological Complexity, 7: 349-358.

Glenn E, Smith M S, Squires V, 1998. On our failure to control desertification: Implications for global change issues, and a research agenda for the future. Environmental Science \& Policy, 1(2): 71-78.

Gou Q Q, Han Z W, Du H Q et al., 2012. Review on sandstorm sources and its control measures in China. Journal of Desert Research, 32(6): 1559-1564. (in Chinese)

Green B H, 1989. Agriculture impacts on the rural environment. Journal of Applied Ecology, 26: 793-802.

Han Y W, Tuo X S, Gao J X et al., 2011. Assessment on the sand-fixing function and its value of the vegetation in eco-function protection areas of the lower reaches of the Heihe River. Journal of Natural Resources, 26(1): 58-65. (in Chinese)

Hardin G, 1968. The tragedy of the commons. Science, 162: 1243-1248.

Hartter J, Goldman A, 2011. Local responses to a forest park in western Uganda: Alternate narratives on fortress conservation. Oryx, 45: 60-68.

Hauser S, Meixler M S, Laba M, 2015. Quantification of impacts and ecosystem services loss in New Jersey coastal wetlands due to hurricane sandy storm surge. Wetlands, 35(6): 1137-1148.

Hofstad O, Araya M M, 2015. Optimal wood harvest in miombo woodland considering REDD + payments: A 
case study at Kitulangalo Forest Reserve, Tanzania. Forest Policy and Economics, 51: 9-16.

Home R, Balmer O, Jahrl I et al., 2014. Motivations for implementation of ecological compensation areas on Swiss lowland farms. Journal of Rural Studies, 34: 26-36.

Hu X F, 2015. Regional ecological compensation mechanism in the view of ecological civilization: Taken Jiangxi province as an example [D]. Nanchang: Nanchang University. (in Chinese)

Huang Q, Sun H B, Wang R H et al., 2007. Effect of oasis land-use and land-cover change on ecosystem service values in typical mountain-oasis-desert system in arid region. Journal of Desert Research, 27(1): 76-81. (in Chinese)

Kolinjivadi V, Adamowski J, Kosoy N, 2014. Recasting payments for ecosystem services (PES) in water resource management: A novel institutional approach. Ecosystem Services, 10: 144-154.

Kosoy N, Corbera E, Brown K, 2008. Participation in payments for ecosystem services: Case studies from the Lacandon rainforest, Mexico. Geoforum, 39(6): 2073-2083.

Kroeger T, Manalo P, 2007. Economic benefits provided by natural lands: Case study of California's Mojave Desert. Washington.

Kwayu E J, Sallu S M, Paavola J, 2014. Farmer participation in the equitable payments for watershed services in Morogoro, Tanzania. Ecosystem Services, 7: 1-9.

Larson J S, Mazzarese D B, 1994. Rapid assessment of wetlands: History and application to management. In: Global Wetlands: Old World and New. Amsterdam: Elsevier, 625-636.

Li G P, Shi H Y, 2015. The payment of grain to green project, the behavior choice of peasants and their gains and losses. China Population, Resources and Environment, 25(5): 152-161. (in Chinese)

Li Y, Li S C, Gao Y et al., 2013. Ecosystem services and hierarchic human well-being: Concepts and service classification framework. Acta Geographica Sinica, 68(8): 1038-1047. (in Chinese)

Liu C L, Liu W D, Lu D D, 2014. A study of the geographical features and implications of eco-compensation. Geographical Research, 33(5): 803-816. (in Chinese)

Liu Z Y, Dong Z B, Wang J B et al., 2015. Practice and development of deserticulture in Inner Mongolia, China: A view of ecosystem service system. Journal of Desert Research, 35(4): 1057-1064. (in Chinese)

Lu C X, Zhao T Y, Shi X L et al., 2016. Ecological restoration by afforestation may increase groundwater depth and create potentially large ecological and water opportunity costs in arid and semiarid China. Journal of Cleaner Production. http://dx.doi.org/10.1016/j.jclepro.2016.03.046.

Luo J, Liu G C, Li C L et al., 2014. Discussion on eco-compensation standard of farmland in northern sandy area of Naiman based on ecosystem service. Journal of Inner Mongolia Forestry Science \& Technology, 40(1): 47-51. (in Chinese)

Lv Z X, Gao B T, 2009. Study on ecological compensation system and land desertification controlling. Journal of Anhui Agri. Sci., 37(32): 15907/15908, 15937. (in Chinese)

MA, 2003. Ecosystem and Human Wellbeing: A Framework for Assessment. Washing DC: Island Press.

MA, 2005. Millennium Ecosystem Assessment: Ecosystems and Human Wellbeing: Synthesis. Washing DC: Island Press.

Mao X Q, Zhong Y, Zhang S, 2002. Conception, theory and mechanism of eco-compensation. China Population, Resources and Environment, 12(4): 38-41. (in Chinese)

Marshall A, 1890. Principles of Economics. Beijing: People's Daily Publishing House.

Martínez-Valderrama J, Ibáñez J, Del Barrio G et al., 2016. Present and future of desertification in Spain: Implementation of a surveillance system to prevent land degradation. Science of the Total Environment, 563/564: $169-178$.

Matthies B D, Kalliokoski T, Eyvindson K et al., 2016. Nudging service providers and assessing service trade-offs to reduce the social inefficiencies of payments for ecosystem services schemes. Environmental Science \& Policy, 55: 228-237.

Mo H W, Ren Z Y, Wang X, 2006. Study on the dynamic change of value of vegetation sand-fixing effect: A case study in the Yuyang region. Arid Zone Research, 23(1): 56-59. (in Chinese)

Mouchet M A, Paracchini M L, Schulp C J E et al., 2017, Bundles of ecosystem (dis)services and multifunctionality across European landscapes. Ecological Indicators, 73: 23-28.

Muñoz-Piña C, Guevara A, Torres J M et al., 2008. Paying for the hydrological services of Mexico's forests: Analysis, negotiations and results. Ecological Economics, 65(4): 725-736. 
Nguyen T T, Pham V D, Tenhunen J, 2013. Linking regional land use and payments for forest hydrological services: A case study of Hoa Binh Reservoir in Vietnam. Land Use Policy, 33: 130-140.

Ni G H, Zheng F T, Ding D et al., 2013. Oasis agriculture, tragedy of the commons and land desertification: A case from Minqin County, Gansu. Journal of Northwest A\&F University (Social Science Edition), 13(3): 12-16. (in Chinese)

Ning Y Y, 2010. The compensation mechanism of the grain for green policy of China [D]. Changchun: Jilin University. (in Chinese)

Ouyang Z Y, Wang X K, Miao H, 1999. A primary study on Chinese terrestrial ecosystem services and their ecological-economic values. Acta Ecologica Sinica, 19(5): 607-613. (in Chinese)

OWG, 2014. OWG Proposal for SDGs.

Pan J, 2014. Main regional eco-compensation and related issues: A case of Beijing and Tianjin sandstorm source region. Journal of Harbin Institute of Technology (Social Science Edition), 16(5): 116-122. (in Chinese)

Peng H, 2013. Eco-hydrological simulation and vegetation water use computation in the Loess Plateau [D]. Beijing: China Institute of Water Resources \& Hydropower Research (IWHR). (in Chinese)

Peng J G, Zhou Y M, An W M et al., 2010. Assessment on functional value of ecosystem service in oasis and desert criss-cross zone in Qitai Region. Xinjiang Agricultural Sciences, 47(8): 1665-1670. (in Chinese)

Portnov B A, Safriel U N, 2004. Combating desertification in the Negev: Dryland agriculture vs. dryland urbanization. Journal of Arid Environments, 56: 659-690.

Ren H C, Sun J M, Zhu L H et al., 2007. Assessment of desert ecosystem service benefits in Western China. Forest Resources Management, (6): 67-69. (in Chinese)

Research Project Group on Monitoring and Evaluation Technology of Desert Ecosystem Service Function, 2014. Study on Function Evaluation and Service Value of Desert Ecosystem. Beijing: Science Press. (in Chinese)

Richardson R B, 2005. The Economic Benefits of California Desert Wildlands: 10 Years since the California Desert Protection Act of 1994. The Wilderness D C: Island Press.

Rodríguez-de-Francisco J C, Budds J, 2015. Payments for environmental services and control over conservation of natural resources: The role of public and private sectors in the conservation of the Nima watershed, Colombia. Ecological Economics, 117: 295-302.

Sagie H, Morris A, Rofè Y et al., 2013. Cross-cultural perceptions of ecosystem services: A social inquiry on both sides of the Israeli-Jordanian border of the Southern Arava Valley Desert. Journal of Arid Environments, 97: 38-48.

Salvati L, Mavrakis A, Colantoni A et al., 2015. Complex adaptive systems, soil degradation and land sensitivity to desertification: A multivariate assessment of Italian agro-forest landscape. Science of the Total Environment, 521/522: 235-245.

Sodhi N S, Lee T M, Sekercioglu C H et al., 2010. Local people value environmental services provided by forested parks. Biodivers \& Conservation, 19: 1175-1188.

State Forestry Administration (SFA), 2015. The fifth national desertification and desertification land monitoring. Chinese Forestry Information.

Sutton P C, Anderson S J, Costanza R et al., 2016. The ecological economics of land degradation: Impacts on ecosystem service values. Ecological Economics, 129: 182-192.

Tian H W, Gao Z L, 2013. Research of causes and control patterns on land desertification in Loess Plateau. Research of Agricultural Modernization, 34(1): 19-24. (in Chinese)

Tschakert P, 2007. Environmental services and poverty reduction: Options for smallholders in the Sahel. Agricultural Systems, 94(1): 75-86.

Twomlow S, Mugabe F T, Mwale M et al., 2008. Building adaptive capacity to cope with increasing vulnerability due to climatic change in Africa: A new approach. Physics \& Chemistry of the Earth Parts A/b/c, 33: 780-787.

UNCCD, 2011. Desertification: A Visual Synthesis.

UNCCD, 2012. Zero Net Land Degradation: A Sustainable Development Goal to Rio+20.

Unkovich M, Nan Z, 2008. Problems and prospects of grassland agroecosystems in western China. Agriculture Ecosystems \& Environment, 124: 1-2.

Wang T, 2004. Study on sandy desertification in China: 3. Key regions for studying and combating sandy desertification. Journal of Desert Research, 24(1): 1-9. (in Chinese)

Wang Y H, 2015. Desert ecosystem service and its responses to the change of land cover: A case study of Shapotou reserve [D]. Lanzhou: Lanzhou University. (in Chinese) 
Wijitkosum S, 2016. The impact of land use and spatial changes on desertification risk in degraded areas in Thailand. Sustainable Environment Research, 26: 84-92.

Wunder S, 2005. Payments for environmental services: Some nuts and bolts. CIFOR Occasional Paper, $42: 24$.

Wunder S, Albán M, 2008. Decentralized payments for environmental services: The cases of Pimampiro and PROFAFOR in Ecuador. Ecological Economics, 65(4): 685-698.

Wunder S, 2015. Revisiting the concept of payments for environmental services. Ecological Economics, 117: $234-243$.

Wuriga, 2013. Analysis of desertification control system and construction of market system in Inner Mongolia [D]. Beijing: Minzu University of China. (in Chinese)

Wünscher T, Engel S, 2012. International payments for biodiversity services: Review and evaluation of conservation targeting approaches. Biological Conservation, 152: 222-230.

Xiao S C, Xiao H L, Lu Q et al., 2013. Evaluation on China desert and sandy land ecosystem services based on its related water process and regulating functions. Journal of Desert Research, 33(5): 1568-1576. (in Chinese)

Xie G D, Lu C X, Leng Y F et al., 2003. Ecological assets valuation of the Tibetan Plateau. Journal of Natural Resources, 18(2): 189-196. (in Chinese)

Xie G D, Zhen L, Lu C X et al., 2008. Expert knowledge based valuation method of ecosystem services in China. Journal of Natural Resources, 23(5): 911-919. (in Chinese)

Xie Z W, Wang K, Cao S X, 2013. The social, economic, and ecological benefit of deserticulture in Ningxia. Pratacultural Science, 30(3): 478-483. (in Chinese)

$\mathrm{Xu}$ M X, 2003. Soil quality evolvement mechanism in the process of ecosystem restoration and its management in the hilly Loess Plateau [D]. Yangling: Northwest Sci-tech University of Agriculture and Forestry. (in Chinese)

Xue Z J, Qin Z D, Meng X W, 2012. Economic loss of sandy desertification in north Shanxi province. Journal of Arid Land Resources and Environment, 26(4): 24-29. (in Chinese)

Yang C L, Bai Y P, 2009. Evaluation of the ecosystem service's value function of an oasis in arid areas: Taking Minqin oasis as an example. Agricultural Research in the Arid Areas, 27(5): 230-234. (in Chinese)

Yang L W, He B Y, Huang P et al., 2006. Assessment of ecological service values for native Populus euphratica forest in Khotan watershed. Acta Ecologica Sinica, 26(3): 681-689. (in Chinese)

Yang L W, Wang D Y, 2009. Evaluation of ecological service value of wind-break and sand-fixation function of Shapotou sand-binding vegetation ecosystem. Journal of Shanxi Normal University (Natural Science Edition), 23(4): 94-98. (in Chinese)

Zhang B, Xie G D, Xiao Y et al., 2010. Classification of ecosystem services based on human needs. China Population, Resources and Environment, 20(6): 64-67. (in Chinese)

Zhang F, Teyibai T, Ding J L et al., 2009. Spatial-temporal changes of land use and ecosystem services value in the north of Tarim Basin: A case study on the Ugan-Kuqa River Delta Oasis. Journal of Desert Research, 29(5): 933-941. (in Chinese)

Zhang F C, Yang X Y, 2007. Analysis of prospects of developing deserticulture in Chaidamu Basin, Qinghai Province. Ecological Economy, (3): 111-115. (in Chinese)

Zhang H, Zhang A P, Yang J, 2007. Effects of land use change on ecosystem service values of Horqin sandy land. China Population, Resources and Environment, 17(3): 60-65. (in Chinese)

Zhang J P, Li Y Q, Zhao X Y et al., 2017. Effects of exclosure on soil physicochemical properties and carbon sequestration potential recovery of desertified grassland. Journal of Desert Research, 37(3): 491-499. (in Chinese)

Zhang J Z, Zhao T Y, Jiang C C et al., 2016. Opportunity cost of water allocation to afforestation rather than conservation of natural vegetation in China. Land Use Policy, 50: 67-73.

Zhang Z Y, 2015. Desertification governance based on ecological economics: An example of Horqin Sandy Land, Inner Mongolia. Journal of Inner Mongolia University for Nationalities, 30(6): 497-502. (in Chinese)

Zhao Q N, Zhu T J, 2015. Hedonic price research on the impact of urban lake landscape on residential property value. Science Technology and Industry, 15(5): 15-18. (in Chinese)

Zhao S D, Zhang Y M, 2006. Ecosystems and human well-being: The achievements, contributions and prospects of the millennium ecosystem assessment. Advances in Earth Science, 21(9): 895-902. (in Chinese) 